\title{
Soil structural condition and its relationship with pastures under different conditions in the Simpson Valley (Humid western Patagonia, Chile)
}

\author{
Estado estructural del suelo y su relación con pasturas bajo diferentes condiciones \\ en el Valle Simpson (Patagonia occidental húmeda, Chile)
}

\author{
Manuel Vial A..$^{*}$, Marco Sandoval E. ${ }^{2}$
}

\begin{abstract}
RESUMEN
Se evaluó la condición estructural del suelo y su relación con praderas bajo diferentes condiciones de uso en el valle Simpson, región de Aysén, Chile ( $45^{\circ} 43^{\prime}$ S, $72^{\circ} 07^{\prime}$ N). El suelo es Andisol, serie Pollux (Typic Hapludands). Las condiciones fueron: Terraza pradera natural degradada (TPD), Terraza pradera sembrada buen estado (TPBE), Silvopastoreo (SP), Lomaje pradera natural degradada (LPD), Lomaje pradera sembrada buen estado (LPBE); en profundidades de 5, 10 y $20 \mathrm{~cm}$. Mediante el método de tamizado en húmedo se determinaron el \% de agregación, macroagregados $\left(\sum \geq 0.25 \mathrm{~mm}\right)$, microagregados $\left(\sum<0.25 \mathrm{~mm}\right)$, estabilidad de agregados (DPM mm) y el Índice de Perdida (IP $\mathrm{g} \mathrm{kg}^{-1}$ ). El diseño experimental usado fue completamente al azar con arreglo de parcelas divididas. Las diferencias se analizaron mediante Tukey $(p \leq 0.05)$. Existió un elevado \% de agregación (77.8 \pm 9.7) y dominio de macroagregados en todos los tratamientos. Se observó mayor estabilidad de agregados en SP (> DPM), seguido por TPBE y LPBE, y menor estabilidad en TPD y LPD. IP correlacionó con DPM $\left(r=-0.723 ; R^{2}=0.567\right)$. Los suelos presentan buenas condiciones estructurales, pero son frágiles. El silvopastoreo es altamente beneficioso en la mantención y mejoramiento de las condiciones físicas de los suelos, seguido de praderas artificiales.
\end{abstract}

Palabras clave: silvopastoreo, agregación, Patagonia, Andisols.

\begin{abstract}
The structural condition of the soil and its relationship with pastures under different conditions in use soil were evaluated in the Simpson Valley, Aysén Region, Chile ( $45^{\circ} 43^{\prime}$ 'S, $72^{\circ} 07^{\prime}$ N). Soils correspond to Andisols, Pollux series (Typic Hapludands). Established conditions were: terrace in degraded natural pasture (TPD), terrace in well-kept planted pasture (TPBE), silvopasture $(S P)$, degraded natural pasture on a hill site (LPD), and well-kept planted pasture on a hill site (LPBE). At depths of 5,10 and 20 $\mathrm{cm}$. Percentage of soil aggregation, macroaggregates $\left(\sum \geq 0.25 \mathrm{~mm}\right)$, microaggregates $\left(\sum<0.25 \mathrm{~mm}\right)$, stability of aggregates $(M W D$ $\mathrm{mm})$ and Loss Index (IP $\left.\mathrm{g} \mathrm{kg}^{-1}\right)$ were determined by wet sieving. The experimental design was a complete randomized in a split plot arrangement. Statistical differences were analyzed using Tukey's tests $(p \leq 0.05)$. A high percentage of aggregation $(77.8 \pm$ 9.7) and a predominance of macroaggregates were observed in all treatments. Higher aggregate stability was observed in SP (> $M W D$ ), followed by TPBE and LPBE, while TPD and LPD showed lower levels of aggregate stability. IP correlated with MWD values $\left(r=-0.723 ; R^{2}=0.567\right)$. Soils presented good physical conditions but fragile nature. Silvopasture is a highly beneficial practice to maintain and improve soil physical conditions of the valley, followed by artificial pastures.
\end{abstract}

Key words: silvopasture, aggregation, Patagonia, Andisols.

\section{Introduction}

\section{Aysén Region and its agricultural production}

The Aysén Region has an area of approximately 10.8 million hectares. The region is divided transversely from west to east into three areas with specific agro-ecological characteristics: the humid area, the intermediate zone and the cold steppe. The intermediate zone has a trans-Andean climate with cold-steppe degeneration, with continental characteristics, with a considerable temperature range and less precipitation than the humid area -. Rainfall ranges from 1000 to $1500 \mathrm{~mm}$ in the valleys and

1 Instituto de Investigaciones Agropecuarias, INIA Carillanca, km 10, camino Cajón-Vilcún s/n, Temuco, Chile.

2 Department of Soils and Natural Resources, Facultad de Agronomía, Universidad de Concepción. Av. Vicente Méndez 595, Chillan.

* Corresponding author: manuel.vial@inia.cl

Fecha de Recepción: 21 Marzo, 2015.

Fecha de Aceptación: 8 Julio, 2015. 
from 500 to $700 \mathrm{~mm}$ in areas of transition towards the cold steppe. Strong westerly winds prevail in spring and summer, what results in water deficit of up to three months. Average temperature in summer ranges from 12 to $14^{\circ} \mathrm{C}$ and from 2 to $3^{\circ} \mathrm{C}$ in winter, with an average minimum of $-4^{\circ} \mathrm{C}$. The frost-free period lasts about four months (November to February) (Silva et al., 1999). The valley of the Simpson River is located in the intermediate zone. It is an exceptional area, with soils fitted for pastures that have supported a remarkable farming activity in the area over many years.

\section{Aggregation}

The permanence, destruction or production of soil aggregates and organic matter content are presented as relevant indicators for soil structure and sustainable use of the system (Carter, 2002). Aggregates are physically stable and quantifiable organometallic complexes that made up soil structure. Aggregates can be modified according to rotation, organic matter content and continuity of the intervention over time (Jastrow et al., 1998; Bronick and Lal, 2005). Six et al. (2000) obtained four different fractions by wet sieving and classified them into microaggregates (53 to $250 \mu \mathrm{m})$, small macroaggregate $(250-2000$ $\mu \mathrm{m})$ and large macroaggregates $(>2000 \mu \mathrm{m})$. Macroaggregates can be formed by the accumulation of microaggregates or particles of organic matter or and exudates from bacterial activity that help bind clay particles together and contribute to soil aggregation (Oades, 1984).

\section{Pasture rotation-crops and structural changes in the soil}

There are changes in land use that deteriorate the soil physical conditions. Livestock production and crop production in forest lands increase bulk density, compaction and reduce infiltration (Reiners et al., 1994). Other changes relate to sites, such as intensive crop rotation, establishment or elimination of pastures and grazing occurrence, which bring about changes in the variation of the pore space and biomass production (Singleton and Addison, 1999; Houlbrooke et al., 2011).

Soil management practices such as no tillage, the establishment of permanent pastures, the presence of legumes and silvopasture are highly positive, as these practices result in increased organic matter content and improved soil aggregation and soil structural stability (Angers, 1992; Haynes, 1999; Atsivor, 2001).

The response of pastures to human disturbance is variable. Grazing has impacts on the composition of species and botanical diversity depending on its intensity (San Martín et al., 2009; Fuentes et al., 2011). In this regard, there is an inherent capacity of pasture species to respond to fertility and soil physical conditions, which is directly reflected in the botanical composition, number of individuals and species diversity, with predominance of the best adapted species over time (Janssens et al., 1998; White et al., 2000; San Martín et al., 2009).

In pastures of southern Chile, there are plant species that develop depending on grazing intensity, fertility (linked to the sulfur and phosphorus deficiency in Andisols), and soil physical conditions (Ramirez et al., 1992; Mora et al., 2002). Ramirez et al. (1992) and San Martín et al. (2009) determined the behavior of certain plant species as ecological indicators of physical factors in the soil, such as light, temperature and humidity, concluding that humidity is the most important factor in the differentiation of dominant species.

The aim of this study is to evaluate both the structural condition of the soil under different physiographic units and its relationship with the conditions of pastures found in the Simpson River Valley.

\section{Materials and Methods}

\section{Site characterization}

The study sites are located in the Simpson River Valley, Commune of Coyhaique, Aysén Region, Western Patagonia, Chile ( $45^{\circ} 43^{\prime}$ S., $72^{\circ} 07^{\prime} \mathrm{N}$, 288 m.a.s.l.) (Figure 1). It is a valley of rolling hills and alluvial terraces. The predominant soils are Andisols, Pollux series (loamy, medial, mesic Typic Hapludands) (Luzio et al., 2009) (Table 1).

\section{Sampling}

Undisturbed samples were extracted by introducing tubes of $110 \mathrm{~mm}$ and $25 \mathrm{~cm}$ long. Particle size and texture class analyses were performed by using the Bouyucos Hydrometer Method. Sampling was conducted in spring 2009. 


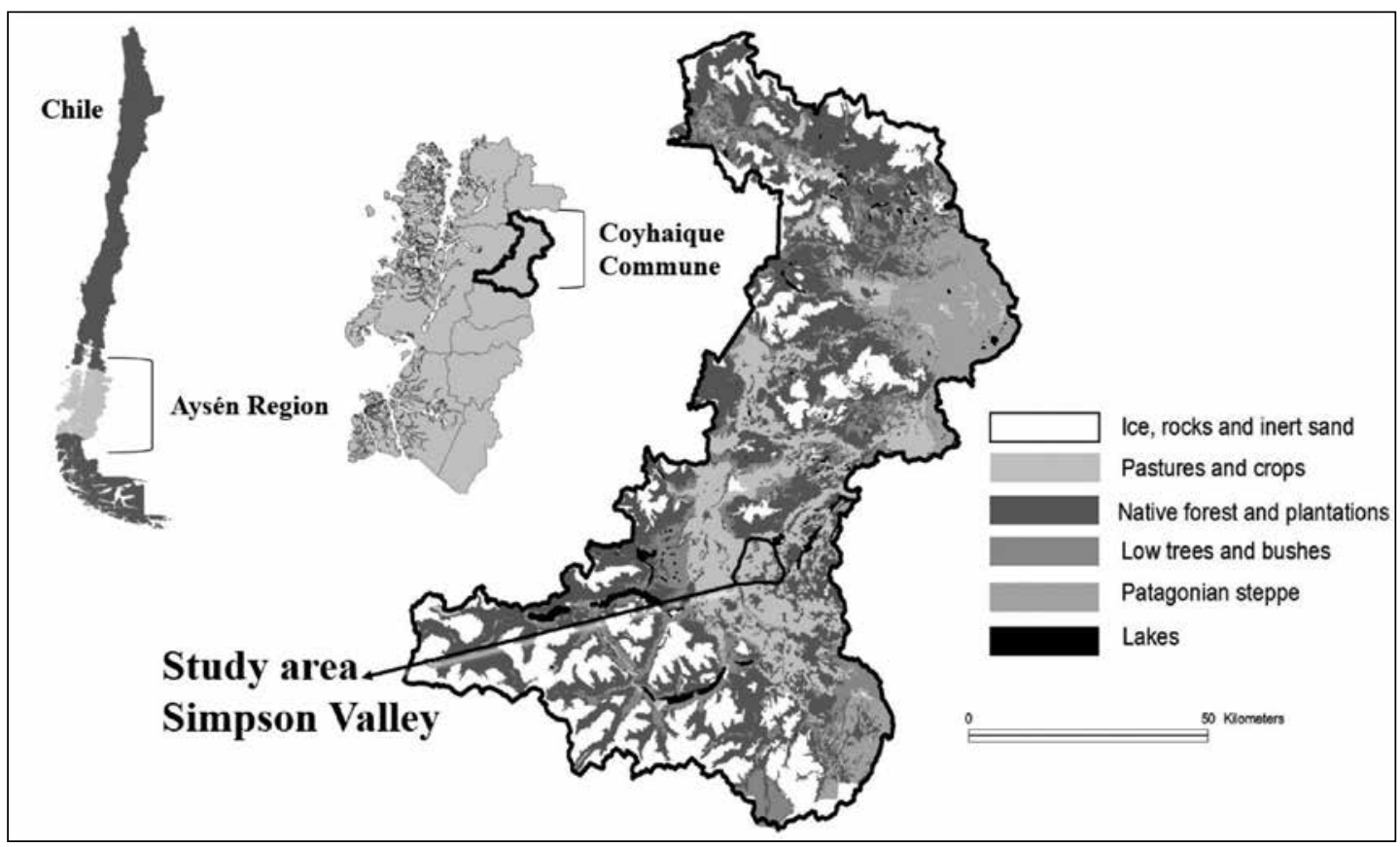

Figure 1. Location of the study area in the region of Aysén, Chile $\left(45^{\circ} 43^{\prime} \mathrm{S}, 72^{\circ} 07^{\prime} \mathrm{N}\right)$.

\section{Determination of aggregate distribution}

The distribution of soil aggregates was determined by wet sieving on dry soil (100 g) (Kemper and Rosenau, 1986), with a frequency of 25 oscillations per minute for 10 minutes. The set of sieves had openings of: $2 \mathrm{~mm} ; 2-1 \mathrm{~mm}$; $1-0.5 \mathrm{~mm}$; 0.5-0.25 mm; 0.25$0.1 \mathrm{~mm} ; 0.1-0.05 \mathrm{~mm}$ and released material $<0.05$ $\mathrm{mm}$, the residue (disintegrated material). The results were separated into percentages of: aggregation $\left(\sum 5\right.$ $\mathrm{mm}-0.053 \mathrm{~mm})$, content of macroaggregates $(\Sigma \geq 0.25$ $\mathrm{mm})$ and content of microaggregates $\left(\sum<0.25 \mathrm{~mm}\right)$ with respect to the treated dry soil $(100 \mathrm{~g})$ by setting the $\%$ as indicator. Organic carbon (OC) in the soil and aggregates were determined by the values of organic matter estimated by a modified WalkleyBlack wet digestion method adapted for Chilean soils divided by 1.724 .

\section{Aggregate stability}

Aggregate stability was determined using the mean weight diameter (MWD): The mean weight diameter of aggregates is an indicator of structural stability, corresponding to the following formula:

$$
\text { [1] } \mathrm{MWD}=\sum x i * w i
$$

[1] Where $x i$ is the mean diameter of the aggregates and wi is the dry mass of soil retained on each aggregate size class of (Kemper and Rosenau, 1986).

\section{Material not retained by the sieves}

The loss index was calculated, IP $\mathrm{g} \mathrm{kg}^{-1}$ which corresponds to the not retained fraction (disintegrated) and defined as the difference between the total mass of dry soil adjusted for the wet sieving method:

$$
\text { [2] } \mathrm{IP}=\left(\mathrm{M}_{\text {total dry }}-\left(\mathrm{MA}_{\mathrm{dry}}+\mathrm{MI}_{\mathrm{dry}}\right)\right) \mathrm{g} \mathrm{kg}^{-1}
$$

[2] IP = Ioss index g kg-1; $\mathrm{M}_{\text {total dry }}=$ total dry soil mass $105^{\circ} \mathrm{C}$ weight $\mathrm{g} ; \mathrm{MA}_{\mathrm{dry}}=$ retained material 2 to $0.25 \mathrm{~mm}$, dry $105^{\circ} \mathrm{C}$ weight; $\mathrm{MI}_{\mathrm{dry}}=$ retained material $<0.25$ to $0.053 \mathrm{~mm}$, dry $105^{\circ} \mathrm{C}$ weight $\mathrm{g}$.

\section{Determination of porosity and penetration resistance}

Bulk density Bd $\left(\mathrm{g} \mathrm{cm}^{-3}\right)$, true density $\mathrm{Td}$ $\left(\mathrm{g} \mathrm{cm}^{-3}\right)$, total porosity (Pt \%), macropores and micropores were determined. Measurements of soil penetration resistance were made using a Field Scout digital cone penetrometer, model SC-900 SC in situ between $0-20 \mathrm{~cm}$ of depth. 


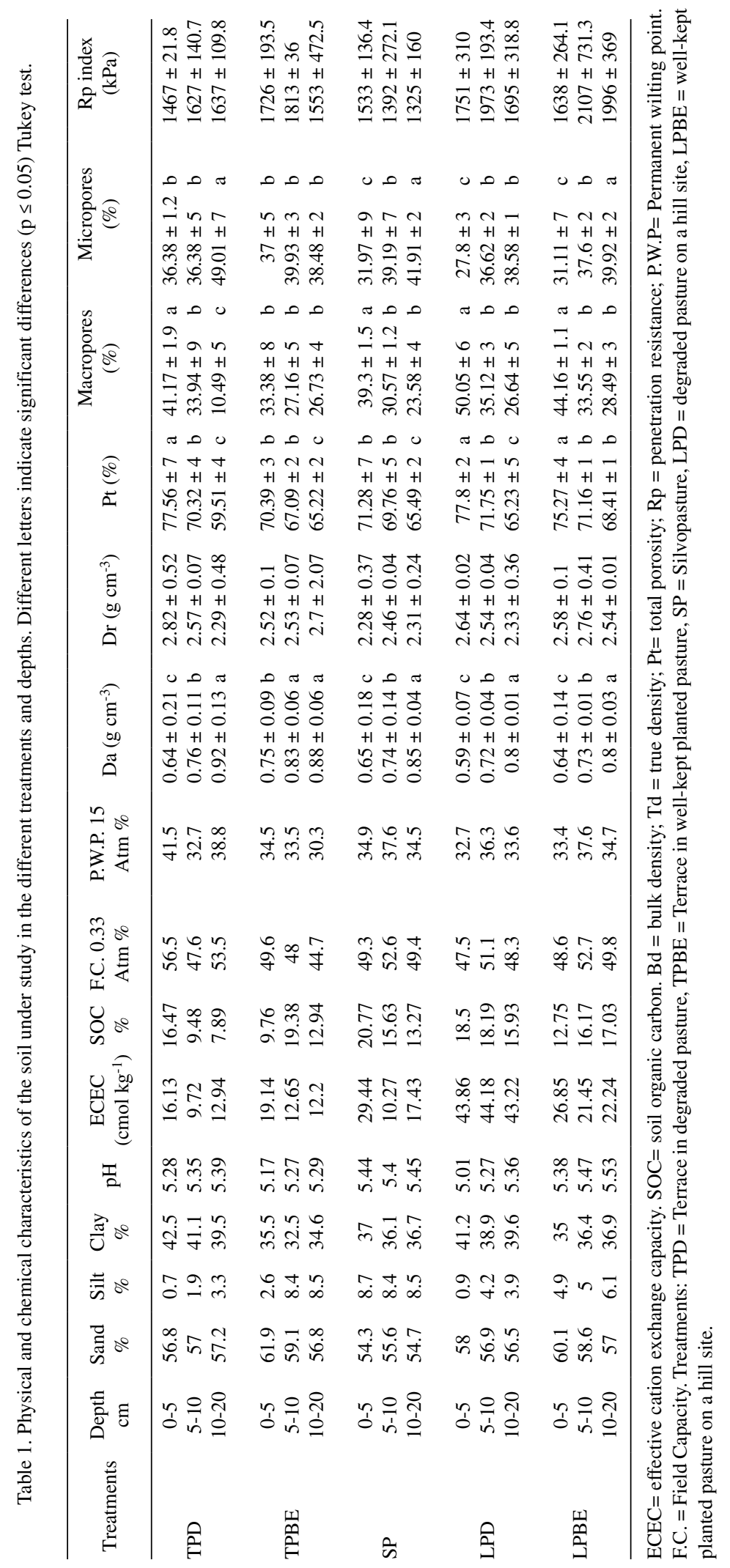


$\operatorname{Pt}(\%)=\left[1-\mathrm{Bd}\left(\mathrm{g} \mathrm{cm}^{-3}\right) /\left(\mathrm{g} \mathrm{cm}^{-3}\right)\right]$

Macropores $(\%)=\mathrm{Pt}-\left[\% \mathrm{Fc} * \mathrm{Bd}\left(\mathrm{g} \mathrm{cm}^{-3}\right)\right]$

Micropores $(\%)=\mathrm{Pt}-\%$ Macropores

$\%$ Fc: $\%$ Field capacity

Bd: bulk density

\section{Treatments}

Five treatments and $(\mathrm{T})$ and three sub-treatments were performed at depths (D) of 0-5, 5-10, 10-20 cm. All treatments are sites under grazing of livestock.

Treatment 1: Terrace in degraded pasture (TPD): Natural pasture in terrace in poor productive condition. Predominance of: Hypochoeris radicata, Plantago sp., Acaena sp., Luzula sp., Cerastium sp., Agrostis sp. and Poa pratense.

Treatment 2: Terrace in well-kept planted pasture (TPBE): artificial pasture in terrace planted with grass and legume species of good forage quality, with prevalence of: Dactylis glomerata, Lolium perenne, Anthoxanthum odoratum, Festuca arudinacea, Trifolium pratense, Trifolium repens, Hypochoeris radicata and Taraxacum officinale.

Treatment 3: Silvopasture (SP): Natural pasture, with prevalence of: Trifolium pratense, Trifolium repens, Dactylis glomerata, Hypochoeris radicata. There are Nothofagus pumilio "Lenga" forests scattered and in low density. The Nothofagus forests are young and in successional stages. Nothofagus pumilio "Lenga" is a deciduous tree.

Treatment 4: Degraded natural pasture on hills (LPD): Hillside of natural pasture, with species of low forage quality. Incipient mantle erosion can be observed. Prevalence of: Acaena sp., Trifolium sp., Hypochoeris radicata.

Treatment 5: Well-kept planted pasture on hills (LPBE): Artificial planted pasture in good productive condition, located on the north slope exposure. Prevalence of: Hypochoeris radicata, Trifolium sp., Trifolium pratense, Trifolium repens, Dactylis glomerata and Holcus lanatus.

\section{Experimental Design}

The General Linear Model (GLM) in SAS () software was used to conduct the data analysis. The experimental design was a randomized complete in a split plot arrangement with sampling. Tests of normality and homogeneity of variances were carried out. The formula $(X+0.5)^{0.5}$ was used in case of not normal distribution and correlations were analyzed. Differences were compared by Tukey test $(p \leq 0.05)$.

\section{Results and Discusion}

\section{Aggregation}

The percentage of aggregation was high in all treatments $(77.8 \pm 9.7 \%)$. SP had the highest percentage value $(85.4 \pm 11.1 \%)$, followed by treatments sited on hills (LPBE $79.5 \pm 8.4 \%$ y LPD $75.2 \pm 6.8 \%$ ) and treatments in terrace (TPBE 74.8 $\pm 11.3 \%$ and TPD $74 \pm 11.3 \%$ ).

The percentage of aggregation obtained in SP is similar to the values reported in Andisols under mature forest and secondary deciduous forests $(86.68 \pm 0.24 \%$ y $90.68 \pm 0.2 \%$, respectively), which stands out the high influence of tree formations on soil aggregation. Similarly, all of the treatments presented percentages of aggregation $>74 \%$, which is higher than the values obtained in other pastures (artificial and naturalized) in Andisols, with 49.8 and $58.6 \%$, respectively (Alvear et al., 2007a; Villablanca et. al., 2009).

\section{Macroaggregates and microaggregates}

Significant differences were found in the content of macroaggregates between the treatments and the interaction T x D $(p \leq 0.05)$. However, no significant differences were observed between depths $(p>0.05)$. The T x D interaction $(p \leq 0.05)$ can be attributed to the depth of intervention of tillage equipment at 0-20 cm (Table 2).

There were significant differences in the content of microaggregates between the treatments $(p \leq$ $0.05)$, but no significant differences $(p>0.05)$ were found between depths or interaction between T x D.

In general, the results indicated in Table 2 show a predominant presence of macroaggregates $\left(\sum \geq 0.25\right.$ $\mathrm{mm})$ in all treatments, with a mean value of 65.8 $\pm 12 \%$. Microaggregates $\left(\left(\sum<0.25 \mathrm{~mm}\right)\right.$ presented a mean value of $12 \pm 4.8 \%$. Proportions remained similar in all the depth ranges included in this study.

The SP treatment showed the highest content of macroaggregates $(78.7 \pm 11.2 \%)$. This result can be explained by the favorable environment of silvopastoral systems to increase biomass in surface soil profiles and by the presence of exudates that promote aggregation (Curaqueo et al., 2010). 
Similarly, the high level of macroaggregates in $\operatorname{LPBE}(66.9 \pm 10.7 \%)$ is related to the establishment of the artificial pasture, formation of a dense root system and specific characteristics of the site. The content of macroaggregates in the other treatments followed the sequence: TPBE $>$ TPD $>$ LPD $(62 \pm 9.8$, $62 \pm 10.8$ y $58 \pm 7.9 \%$ ), respectively.

The content of microaggregates was related to the sequence LPD $>$ TPBE $>$ LPBE $>$ TPD $>$ SP, where LPD showed the highest values $(16.2 \pm 4.5 \%)$. These results are explained by disturbing events, certain conditions of the site such as overgrazing, climate, radiation exposure (north hillside), and humidity fluctuations such as summer drought, as evidenced by the presence of plant species characterized by a deep rooting.

\section{Mean Weight Diameter (MWD)}

Mean weight diameter MWD is an indicator of aggregate stability. Statistical analysis shows significant differences in the values of MWD and interaction between treatments $\mathrm{T} \times \mathrm{D}(p \leq 0.05)$. No significant differences were observed in depths (Table 2). The significant interaction T x D in MWD can be explained by the anthropogenic interventions derived from the use of tillage equipment in these sites (0-20 cm depth).

The MWD level analysis between treatments was conduced according to the reference of Le Bissonnais (1996). It was established that SP treatment presented more stable aggregates $(1.3-2$ $\mathrm{mm}$ level), followed by the treatments of terrace in artificial pasture and on hills (TPBE and LPBE), which reached an intermediate level $(0.8-1.3 \mathrm{~mm})$ of aggregate stability. Natural degraded pastures (TPD and LPD) presented unstable aggregates (0.4-0.8 mm level). The highest values of MWD were observed at depths of 5-10>0-5>10-20 cm, which is classified as an intermediate level of aggregate stability, between unstable and stable (0.8-1.3 mm).

The behavior of SP is related to the fungusplant root associations of Nothofagus forests, whose exuded substances and biological activity stabilize soil aggregates that show these higher values when analyzed (Alvear et al. 2007b; Borie et al., 2008). In this regard, Alvear et al. (2007a) found a high correlation $(r>0.9)$ between parameters of soil biological activity and aggregate stability in soils of deciduous forests of the genus Nothofagus.
The treatments in artificial pastures LPBE and TPBE showed lower values of aggregate stability $(0.84 \pm 0.22$ and $1.01 \pm 0.36$, respectively) than SP $(1.64 \pm 0.43)$, but higher values than treatments of natural degraded pastures TPD and LPD (0.68 \pm 0.13 and $0.68 \pm 0.15$, respectively). There is a relationship between artificial pasture and high aggregate stability values, which can explained by pasture vigor, increase of biomass and formation of a dense root system that stimulate exudates which promote soil aggregation. The influence of legumes in the composition of the pasture can also account for this finding (Angers, 1992; Sandoval et al., 2011).

These results are consistent with those reported by Haynes et al. (1991) regarding the influence of crop rotation-pasture in aggregate stability and the relationship between the presence of pastures and increased aggregate stability. At the same time, the values of MWD allow establishing a relationship between the status of 'degraded pasture' (LPD and TPD) and a lower aggregate stability.

\section{Index Loss of dry soil (IP)}

IP corresponds to the material that is not retained by the sieves expressed as $\mathrm{g} \mathrm{kg}^{-1}$, when the wet sieving method is applied (disintegrated material). Results indicate that the treatments TPBE and LPD recorded the highest values in disintegrated material $\left(252.39 \pm 113.24 \mathrm{~g} \mathrm{~kg}^{-1}\right.$ and $248.37 \pm 67.80 \mathrm{~g} \mathrm{~kg}^{-1}$, respectively), followed by TPD with $243.79 \pm 123.80 \mathrm{~g} \mathrm{~kg}^{-1}$ and LPBE with $205.03 \pm 83.98 \mathrm{~g} \mathrm{~kg}^{-1}$. SP recorded the lowest value $\left(146.05 \pm 109.9 \mathrm{~g} \mathrm{~kg}^{-1}\right)$. No significant differences were found between treatments $(\mathrm{T})$ $(p>0.05)$ (Table 2 y 3$)$.

Significant differences were found in depths (D) $(p \leq 0.05)$. The highest values were obtained at depths of 0-5 cm with $263 \pm 122 \mathrm{~g} \mathrm{~kg}^{-1}, 5-10 \mathrm{~cm}$ with $231 \pm 97 \mathrm{~g} \mathrm{~kg}^{-1}$ and $10-20 \mathrm{~cm}$ with $164 \pm 76$ $\mathrm{g} \mathrm{kg}^{-1}$. This variation in depth might not be related to aggregation, but to aggregate stability and pore space variation that occurs in a disturbing event, particularly related to the power at which the water enters the pore space when applying the wet sieving method. An increase of IP $\mathrm{g} \mathrm{kg}^{-1}$ was observed when the $\% \mathrm{Pt}(r=0.648, p<0.01)$ increased. The $\%$ macropores $(r=0.544, p<0.05)$ also increased and a reverse effect to the increase in ${\mathrm{Bd} \mathrm{g} \mathrm{cm}^{-3}}^{-3}$ $(r=-0.528 ; p<0.05)$ was observed. 
Table 2. Sources of variation, degrees of freedom, mean squares and significance in Macroaggregates (\%), Microaggregates (\%), MWD mm, IP Loss Index $\left(\mathrm{g} \mathrm{kg}^{-1}\right)$, Bd bulk density $\left(\mathrm{g} \mathrm{cm}^{-3}\right)$, Td true density $\left(\mathrm{g} \mathrm{cm}^{-3}\right)$ and interactions.

\begin{tabular}{ccccccccc}
\hline $\begin{array}{c}\text { Source } \\
\text { of variation }\end{array}$ & DF & $\begin{array}{c}\text { Macroaggregates } \\
\left(\sum \geq 0.25 \mathrm{~mm}\right)\end{array}$ & $\begin{array}{c}\text { Microaggregates } \\
\left(\sum \geq 0.25 \mathrm{~mm}\right)\end{array}$ & $\begin{array}{c}\text { MWD } \\
(\mathrm{mm})\end{array}$ & $\begin{array}{c}\text { Loss Index } \\
\mathrm{IP}\left(\mathrm{g} \mathrm{kg}^{-1}\right)\end{array}$ & $\mathrm{DF}$ & $\begin{array}{c}\mathrm{Bd} \\
\left(\mathrm{g} \mathrm{cm}^{-3}\right)\end{array}$ & $\begin{array}{c}\mathrm{Td} \\
\left(\mathrm{g} \mathrm{cm}^{-3}\right)\end{array}$ \\
\hline Treatment (T) & 4 & $0.107^{*}$ & $0.020615^{*}$ & $2.8604^{*}$ & $0.03648 \mathrm{~ns}$ & 4 & $0.018 \mathrm{~ns}$ & $0.39 \mathrm{~ns}$ \\
Error (a) & 10 & 0.018 & 0.003 & 0.051 & 0.033 & 10 & 0.024 & 0.309 \\
Depth (D) & 2 & $0.011 \mathrm{~ns}$ & $0.002 \mathrm{~ns}$ & $0.058 \mathrm{~ns}$ & $0.077^{*}$ & 2 & $0.139^{*}$ & $0.02 \mathrm{~ns}$ \\
T x D & 8 & $0.043^{*}$ & $0.002 \mathrm{~ns}$ & $0.596^{*}$ & $0.011^{*}$ & 8 & $0.003 \mathrm{~ns}$ & $0.428 \mathrm{~ns}$ \\
Error (b) & 65 & 0.005 & 0.001 & 0.025 & 0.005 & 20 & 0.005 & 0.348 \\
C. of V. (\%) & & 9.6 & 28.6 & 16.1 & 31.65 & & 8.9 & 22.75 \\
\hline
\end{tabular}

*Significant $p \leq 0.05$; ns: not significant.

Table 3. Microaggregates $\left(\sum<0.25 \mathrm{~mm} \%\right)$, macroaggregates $\left(\sum \geq 0.25 \mathrm{~mm} \%\right)$, mean weight diameter (MWD mm) and loss index (IP g kg${ }^{-1}$ ). Different capital letters indicate differences between treatments. Different lowercase letters indicate differences between depths ( $\mathrm{p} \leq 0.05)$ by Tukey's multiple comparison test.

\begin{tabular}{|c|c|c|c|c|c|c|}
\hline Treatments & $\begin{array}{l}\text { Depth } \\
\text { (cm) }\end{array}$ & $\begin{array}{l}\text { Microaggregates } \\
\left(\sum<0.25 \mathrm{~mm}\right)\end{array}$ & $\begin{array}{c}\text { Macroaggregates } \\
(\Sigma \geq 0.25 \mathrm{~mm})\end{array}$ & MWD (mm) & $\begin{array}{l}\text { Loss Index } \\
\text { IP g kg-1 }\end{array}$ & \\
\hline \multirow{4}{*}{ TPD } & $0-5$ & $12.3 \pm 3.3 \mathrm{ab}$ & $59.9 \pm 16.4 \mathrm{~b}$ & $0.61 \pm 0.15 \mathrm{~d}$ & $361.08 \pm 117$ & $\mathrm{a}$ \\
\hline & $5-10$ & $11.5 \pm 2.4 \mathrm{ab}$ & $60.5 \pm 8.8 \quad \mathrm{c}$ & $0.66 \pm 0.08 \mathrm{~cd}$ & $229.48 \pm 82.56$ & $\mathrm{~b}$ \\
\hline & $10-20$ & $11.1 \pm 1.9 \mathrm{ab}$ & $66.8 \pm 4.5 \quad b$ & $0.76 \pm 0.09 \mathrm{c}$ & $140.8 \pm 44.36$ & $\mathrm{~b}$ \\
\hline & $0-20$ & $11.6 \pm 2.5$ & $62.4 \pm 10.8$ & $0.68 \pm 0.13$ & $243.79 \pm 123.8$ & \\
\hline \multirow{4}{*}{ TPBE } & $0-5$ & $11.2 \pm 3.6 \mathrm{ab}$ & $59 \pm 11.1 \mathrm{~b}$ & $0.89 \pm 0.27 \mathrm{~b}$ & $320.85 \pm 113$ & $a b$ \\
\hline & $5-10$ & $13.5 \pm 2.6 \mathrm{ab}$ & $62.3 \pm 5.1 \quad b c$ & $0.87 \pm 0.17 \mathrm{~b}$ & $246.31 \pm 113$ & $a b$ \\
\hline & $10-20$ & $13.2 \pm 5 \quad \mathrm{ab}$ & $64.9 \pm 12.6 \mathrm{bc}$ & $0.77 \pm 0.22 \mathrm{c}$ & $190 \pm 86.92$ & $\mathrm{~b}$ \\
\hline & $0-20$ & $12.6 \pm 3.7$ & $62.1 \pm 9.8$ & $0.84 \pm 0.22$ & $252.39 \pm 113$ & \\
\hline \multirow{4}{*}{ SP } & $0-5$ & $8 \pm 4.6 \mathrm{~b}$ & $65.5 \pm 9.2 \quad \mathrm{ab}$ & $1.1 \pm 0.3 \quad \mathrm{ab}$ & \multicolumn{2}{|c|}{$147.26 \pm 127.48 b$} \\
\hline & $5-10$ & $6.3 \pm 2.4 \mathrm{~b}$ & $87.2 \pm 1.7 \quad$ a & $1.97 \pm 0.13 \mathrm{a}$ & \multicolumn{2}{|c|}{$163.99 \pm 113.02 b$} \\
\hline & $10-20$ & $6 \pm 1 \quad b$ & $83.4 \pm 3.7 \quad \mathrm{a}$ & $1.84 \pm 0.07 \mathrm{a}$ & \multicolumn{2}{|c|}{$126.91 \pm 105.89 \mathrm{~b}$} \\
\hline & $0-20$ & $6.8 \pm 2.7$ & $78.7 \pm 11.2$ & $1.64 \pm 0.43$ & \multicolumn{2}{|c|}{$146.05 \pm 109.9$} \\
\hline \multirow{4}{*}{ LPD } & $0-5$ & $14.1 \pm 2.5 \mathrm{a}$ & $57.5 \pm 3.9 \quad$ b & $0.64 \pm 0.06 \mathrm{~cd}$ & $270.04 \pm 62.96$ & $\mathrm{a}$ \\
\hline & $5-10$ & $16.6 \pm 4.2 \mathrm{a}$ & $55 \pm 7.1 \quad \mathrm{c}$ & $0.64 \pm 0.13 \mathrm{~cd}$ & $281.32 \pm 53.51$ & $\mathrm{a}$ \\
\hline & $10-20$ & $17.9 \pm 6 \quad a$ & $64.5 \pm 9.7 \quad b c$ & $0.75 \pm 0.21 \mathrm{c}$ & $193.77 \pm 57.97$ & $\mathrm{~b}$ \\
\hline & $0-20$ & $16.2 \pm 4.5$ & $58 \pm 7.9$ & $0.68 \pm 0.15$ & \multicolumn{2}{|c|}{$248.37 \pm 67.8$} \\
\hline \multirow{4}{*}{ LPBE } & $0-5$ & $10.2 \pm 4 \quad a b$ & $76.1 \pm 4.4 \quad \mathrm{a}$ & $1.44 \quad 0.08 \mathrm{a}$ & $215.7 \pm 74$ & $\mathrm{~b}$ \\
\hline & $5-10$ & $12.4 \pm 4.2 \mathrm{ab}$ & $69.9 \pm 7.7 \quad b$ & $0.95 \pm 0.14 \mathrm{ab}$ & \multicolumn{2}{|c|}{$231.96 \pm 104.46 \mathrm{ab}$} \\
\hline & $10-20$ & $15.2 \pm 4.8 \mathrm{ab}$ & $54.7 \pm 4.4 \quad \mathrm{c}$ & $0.63 \pm 0.1 \quad \mathrm{~d}$ & $167.42 \pm 69.89$ & $\mathrm{~b}$ \\
\hline & $0-20$ & $12.6 \pm 4.3$ & $66.9 \pm 10.7$ & $1.01 \pm 0.36$ & $205.03 \pm 83.98$ & \\
\hline
\end{tabular}

Treatments: TPD = Terrace in degraded pasture, $\mathrm{TPBE}=$ Terrace in well-kept planted pasture, $\mathrm{SP}=$ Silvopasture, $\mathrm{LPD}=$ degraded pasture on a hill site, $\mathrm{LPBE}=$ well-kept planted pasture on a hill site. 
In turn, aggregate stability, measured as MWD $\mathrm{mm}$, was negatively correlated with IP $(r=-0.723$; $\left.R^{2}=0.5677 ; p<0.05\right)$. This allows concluding that the lower the aggregate stability is the higher the IP. The regression parameters that define the logarithmic expression of the relationship are indicated graphically in Figure 2. This relates to a particular behavior of volcanic soils in contrast with other types of soils regarding susceptibility to disaggregation and risk of erosion due to the physical effect of water (Mora et al., 2003). Thus, MWD is a suitable indicator to measure the level of aggregation in relation to the incident energy of water by the wet sieving method. Further research on the behavior of the curve in relation to MWD $\mathrm{mm}$ and IP $\mathrm{g} \mathrm{kg}^{-1}$ is required.

Regarding other parameters of aggregation and OC $\%$, it was determined that there is a positive correlation between IP $\mathrm{g} \mathrm{kg}^{-1}$ and the OC $\%$ of aggregates $(r=0.246, p<0.05)$ and the OC \% of microaggregates $(r=0.477, p<0.01)$. With respect to this relationship, it is concluded that in the sites with the highest IP $\mathrm{g} \mathrm{kg}^{-1}$, the\% of OC in microaggregates increases in a linear relationship. There were no significant correlations between the $\%$ of macroaggregates or microaggregates and the IP $\mathrm{g} \mathrm{kg}^{-1}$.

These results allow us to infer a relationship between degraded systems (TPD and LPD degraded pastures), a higher value of IP $\mathrm{g} \mathrm{kg}^{-1}$, increased microaggregation and a higher $\%$ of $\mathrm{OC}$ in microaggregates. This would confirm findings reported by several authors regarding the physical resistance and stability of microaggregates against disruptive processes and reservoir of OC (Oades, 1984; Jastrow et al., 1998; Denef et al., 2004).

\section{Conclusions}

The structural condition of the soil with respect to porosity, degree of compaction and bulk density are not strongly associated with the current conditions of the pastures of the Simpson River valley. However, despite of the high aggregation level observed in

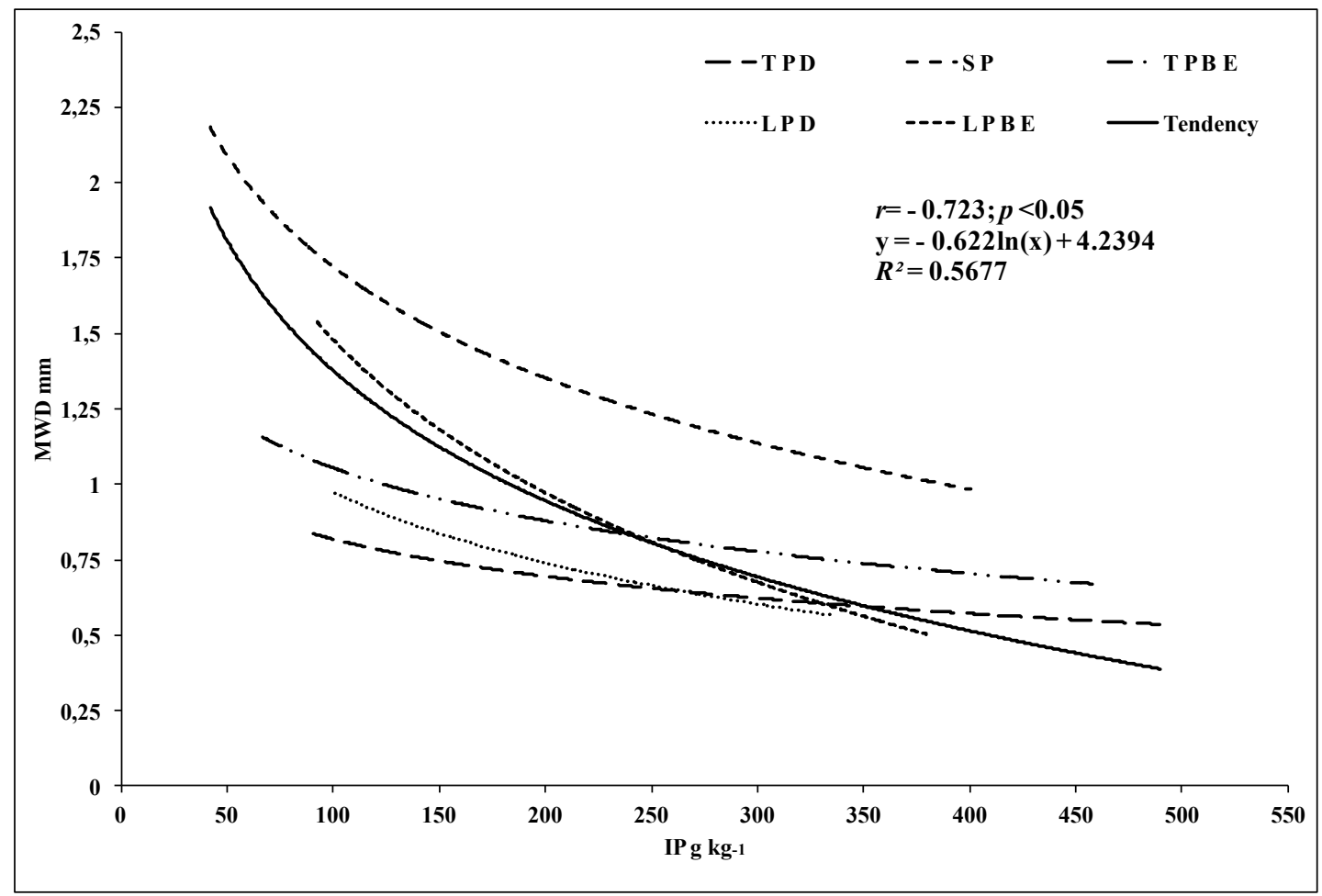

Figure 2. Relationship between Loss Index IP $\mathrm{g} \mathrm{kg}^{-1}$ and Mean Weight Diameter MWD mm. Mean values of treatments and depth of $0-20 \mathrm{~cm} \mathrm{n}=90$. Treatments: TPD $=$ Terrace in degraded pasture, TPBE $=$ Terrace Planted in well-kept pasture, $\mathrm{SP}=\mathrm{Silvopasture}$, $\mathrm{LPD}=$ degraded pasture on a hill site, well-kept LPBE = Planted pasture on a hill site and tendency expressed an logarithmic model. 
all treatments, there is a relationship between the condition of the pasture, the level of aggregation and aggregate stability. In addition, silvopastures are found in better conditions, followed by artificial pastures.

Similarly, there is a relationship between the degraded pastures and a reduced macroaggregation and low aggregate stability.

The wet sieving method determined an inverse relationship between the disintegrated material and aggregate stability called loss index $\left(\mathrm{g} \mathrm{kg}^{-1}\right)$. Similarly, loss index is higher as the soil presents higher levels of microaggregation. This relates to the condition of 'degradation' of the pastures under study.

It is concluded that silvopastoral systems prevent degradation processes, as silvopasture presented lower levels of loss index, higher levels of aggregation and aggregate stability.

\section{Aknowledgements}

This research was financed by the Direction of Investigation University of Concepción. Proyecto Semilla Patagonia. (DIUC 209.123.011-1sp).

\section{Literature Cited}

Alvear, M.; Reyes, F.; Morales, A.; Arriagada, C.; Reyes, M. 2007a. Actividad biológica y agregados estables al agua en dos tipos de formaciones vegetales de un bosque templado del centro-sur de Chile con perturbación antrópicas. Ecología Austral, 17: 113-122.

Alvear, M.; Urra, C.; Huaiquilao, R.; Astorga, M.; Reyes, F. 2007b. Actividades biológicas y estabilidad de agregados en un suelo del bosque templado chileno bajo dos etapas sucesionales y cambios estacionales. J. Soil Sci. Plant Nutr., 7(3): 38-50.

Angers, D.A.

1992. Changes in soil aggregation and organic carbon under com and alfalfa. Soil Sci. Soc. Am. J., 56: 1244-1249.

Atsivor L., G.N.; Dowuona, G.N.; Adiku, S.G.K.

2001. Farming system-induced variability of some soil properties in a sub-humid zone of Ghana. Plant and Soil., 236: 83-90.

Borie, F.; Rubio, R.; Morales, A.

2008. Arbuscular mycorrhizal fungi and soil aggregation. J. Soil Sc. Plant Nutr., 8(2): 9-18.

Bronick, C.J.; Lal, R.

2005. Soil structure and management, a review. Geoderma, 124: 3-22.

Carter, M.R.

2002. Soil Quality for Sustainable Land Management, Organic Matter and Aggregation Interactions that Maintain Soil Functions. Agron., J. 94: 38-47.

Curaqueo, G.; Acevedo, E.; Cornejo, P.; Seguel, A.; Rubio, R.; Borie, $\mathrm{F}$.

2010. Tillage effect on soil organic matter, mycorrhizal hyphae and aggregates in a mediterranean agroecosystem. J. Soil Sc. Plant Nutr., 10(1): 12-21.

Denef, K.; Six, J.; Merckx, R.; Paustian, K.

2004. Carbon Sequestration in Microaggregates of No-Tillage Soils with Different Clay Mineralogy. Soil Sci. Soc. Am. J., 68: 1935-1944.

Fuentes, A.; Pauchard, A.; Hauenstein, E.

2011. Composición de la flora en praderas andinas en la Reserva Nacional Alto Bío-Bío (Lonquimay-Chile) y su relación en el régimen de pastoreo. Gayana Bot., (1): 28-39.

Haynes, R.J.

1999. Labile organic matter fractions and aggregate stability under short-term, grass-based leys. Soil Biol. and Biochem, 31: 1821-1830.
Haynes, R.J.; Swift, R.S.; Stephen, R.C.

1991. Influence of mixed cropping rotations (pasture arable) on organic-matter content, water stable aggregation and clod porosity in a group of soils. Soil and Tillage Research, 19 (1): 77-87.

Houlbrooke, D.J.; Paton, R.J.; Littlejohn, R.P.; Morton, J.D.

2011. Land-use intensification in New Zealand: effects on soil properties and pasture production. Journal of Agricultural Science, 149: 337-349.

Janssens, F.; Peeters, A.; Tallowin, J.R.B.; Bakker, J.P.; Bekker,

R.M.; Fillat, F.; Oomes, M.J.M.

1998. Relationship between soil chemical factors and grassland diversity. Plant and Soil, 202: 69-78.

Jastrow, J.D.; Miller, R.M.; Lussenhop, J.

1998. Contributions of interacting biological mechanisms to soil aggregate stabilization in restored prairie. Soil Biol. Biochem. 30(7): 905-916.

Kemper, W.; Rosenau R.

1986. Aggregate stability and size distribution. In, Klute, A. (ed). Methods of Soil Analysis, Part I. Agronomy Monographs, 9. American Society Agronomy, Madison, WI. pp. 425-442.

Le Bissonnais, Y.

1996. Aggregate stability and assessment of soil crustability and erodibility, I. Theory and methodology. Eur. J. Soil Sci., 47: 425-437.

Luzio, W.; Seguel, O.; Casanova, M.

2009. Suelos de la Zona Húmeda (Desde $43^{\circ}$ LS hasta $50^{\circ}$ LS). P., 263-289. En, Suelos de Chile (Luzio, W., Editor). Universidad de Chile.

Mora M.L.; Cartes P.; Demanet R.; Cornforth I.S.

2002. Effects of lime and gypsum on pasture growth and composition on an acid Andisol in Chile, South America, Communications in Soil Science and Plant Analysis, 33,1314: 2069-2081.

Mora, J.L.; Guerra, J.A.; Notario, J.S.; Rodríguez, A.R.; Arbelo, C.D.

2003. Parámetros físico-químicos que influyen en la erodabilidad de andosoles y suelos andicos bajo vegetación forestal (I. Canarias). Edafología, 10 (2): 207-213.

Oades, J.M.; Waters, A.G.

1991. Aggregate hierarchy in soils. Aust. J. Soil Res., 29: 815-828. 
Ramírez, C.; San Martin, C.; Finot, V.; Ríos D.

1992. Evaluación de praderas usando indicadores ecológicos. Agro sur, 20 (2): 85-100.

Reiners W.A.; Bouwman A.F.; Parsons W.F.; Keller, M. 1994. Tropical Rain Forest Conversion to Pasture, Changes in Vegetation and Soil Properties. Ecological Applications, 4(2): 363-377.

San Martín, C.; Villagra J.; Novoa, C.

2009. Comparación de manejos pratenses del centro-sur de Chile utilizando valores bioindicadores de Ellenberg. Gayana Bot., 66(2): 158-170.

Sandoval, M.; Celis, J.E.; Morales, P.

2011. Structural remediation ofan Alfisol by means of sewage sludge amendments in association with yellow serradela (Ornithophus compressus L.). J.Soil Sci. Plant Nutr., 11(1): 68-78.

Silva, L.F.; Ahumada C.M.; Cerda C.J.

1999. Guía de condición para los pastizales de la ecorregión templada intermedia de Aysén. Proyecto FNDR-SAG XI Región de Aysén, "Levantamiento para el ordenamiento de los ecosistemas de Aysén". Gobierno Regional de Aysén. Ministerio de Agricultura. Servicio Agrícola y Ganadero. Departamento de Recursos Naturales Renovables. 128 p.
Singleton, P. L.; Addison, B.

1999. Effects of cattle treading on physical properties of three soils used for dairy farming in the Waikato, North Island, New Zealand. Australian Journal of Soil Research, 37(5): 891-902. Six, J.; Paustian, K.; Elliott, E.T.; Combrink, C.

2000. Soil structure and organic matter, I. Distribution of aggregate-size classes and aggregate-associated carbon. Soc. Am. J. 64: 681-689.

Villablanca, C.; Curaqueo, G.; Alfaro, M.; Borie, G.; Borie, F. 2009. Niveles de gomalina y su relación con parámetros físicos en suelos de la zona sur de Chile bajo distintos tipos de pradera. XI Congreso Nacional de la Ciencia del Suelo, Chillán, Chile. Universidad de Concepción, Chillán, Chile. SSN0716-6192. Boletín $\mathrm{N}^{\circ} 21$. Sociedad Chilena de Ciencia del Suelo. $256 \mathrm{p}$.

White, R.E.; Helyar, K.R.; Ridley, A.M.; Chen, D.; Heng, L.K.; Evans, J.; Fisher, R.; Hirth, J.R.; Mele, P.M.; Morrison, G.R.; Cresswell, H.P.; Paydar, Z.; Dunin, F.X.; Dove, H.; Simpson, R.J.

2000. Soil factors affecting the sustainability and productivity of perennial and annual pastures in the high rainfall zone of south-eastern Australia. Australian Journal of Experimental Agriculture. 40: 267-283. 